\title{
Lower limb salvage surgery using llizarov circular external frame for a landmine injury about the knee
}

\author{
Diz çevresini etkileyen mayın yaralanması için İlizarov sirküler eksternal çerçeve kullanılarak alt \\ ekstremite kurtarma cerrahisi
}

\author{
Bahtiyar Demiralp, M.D., ${ }^{1}$ Cengiz Yıldırım, M.D., ${ }^{2}$ Yüksel Yurttaş, M.D., ${ }^{1}$ \\ Engin Illker Çiçek, M.D., ${ }^{3}$ Mustafa Başbozkurt, M.D. ${ }^{1}$ \\ 'Department of Orthopedics and Traumatology, Gülhane Military Medical Academy, Ankara, Turkey \\ ${ }^{2}$ Department of Orthopedics and Traumatology, Tatvan Military Hospital, Bitlis, Turkey \\ ${ }^{3}$ Department of Orthopedics and Traumatology, Gölcük Military Hospital, Kocaeli, Turkey
}

\begin{abstract}
Limb salvage for severe trauma has been replaced amputation as the primary treatment in many trauma centers. However, the long-term outcomes after limb reconstruction or amputation have not been fully evaluated. In this report, we present the treatment results of limb salvage surgery using Ilizarov external circular frame in a male case who had a-22-cm bone loss on the left distal femur and left proximal tibia and large soft tissue defect around the knee due to stepping on a landmine with his knee. The decision to amputate a severely injured limb, being irreversible, is challenging and significantly affects the body image and the patient. Extremity salvage surgery should be considered initially when evaluating patients with high-energy injured limbs at high risk for amputation.
\end{abstract}

Key words: External frame; Ilizarov method; landmine; limb salvage.

In the orthopedic trauma literature, there is extensive debate surrounding the decision whether to amputate or reconstruct a severely injured leg. ${ }^{[1,2]}$ In the past two decades, medical and surgical developments have improved the ability to reconstruct severely injured legs. ${ }^{[1-3]}$

Some investigators have concluded that the outcomes in patients who underwent limb salvage surgeries were not significantly different from those of patients who underwent amputation. ${ }^{[4,5]}$

In this case report, we describe a patient who presented with severe injury on his left knee by
Ekstremite kurtarma cerrahisi, çoğu travma merkezinde ciddi yaralanmalarda primer tedavi olarak amputasyonun yerini almıştır. Ancak, ekstremite rekonstrüksiyonu veya amputasyonu sonrası uzun-dönem sonuçlar tam olarak değerlendirilmemiştir. Bu yazıda, dizi ile mayına basma sonucu sol distal femur ve sol proksimal tibiada $22 \mathrm{~cm}$ kemik kaybı ve diz çevresinde geniş yumuşak doku hasarı gelişen erkek hastada İlizarov eksternal sirküler çerçeve kullanılarak yapılan ekstremite kurtarma cerrahisinin tedavi sonuçları sunuldu. Ciddi bir şekilde yaralanmış ekstremiteyi ampute etme kararı, geri dönüşümsüz olarak, zordur ve önemli ölçüde vücut görüntüsünü ve hastayı etkiler. Ekstremite kurtarma cerrahisi, öncelikle amputasyon riski yüksek olan yüksek-enerjili ekstremite yaralanmalı hastalarda göz önünde bulundurulmalıdır.

Anahtar sözcükler: Eksternal çerçeve; İlizarov yöntemi; kara mayını; ekstremite kurtarma.

stepping on an anti-personnel landmine, treated with limb salvage surgery. Our case focuses on limb salvage surgery when evaluating a high-energy injured extremity. Finally, the aim of this study is to emphasize that limb salvage surgery is a difficult and long lasting treatment alternative for high-energy injured extremities.

\section{CASE REPORT}

A large bone and soft tissue deficiency in the left knee region with an injury of Gustilo-Anderson type III-C developed in a 24-year-old-man after kneeling on an

- Received: January 18, 2012 Accepted: September 26, 2012

- Correspondence: Cengiz Yıldırım, M.D. GATA Haydarpaşa Eğitim Hastanesi Ortopedi ve Travmatoloji Kliniği, 34668 Üsküdar, İstanbul, Turkey. Tel: +90 216 - 5422020 Fax: +90 216-542 2089 e-mail: drcengizyildirim@yahoo.com 
anti-personnel landmine with his left knee in March 1998.

First aid was performed in a field hospital where his initial physical examination revealed loss of the patella, large soft tissue deficiency of the patellar tendon, quadriceps tendon and anterior muscle groups with large bone defects of the proximal tibia and distal femur. Popliteal, tibial and femoral arteries were intact on the posterior side. The peroneal nerve was also affected. Injuries were also sustained by the posterior muscle groups without any defect. According to the information presented in this condition, the patient had good lower leg viability with a MESS score 6, but due to extensive bone and soft tissue defects and peroneal nerve injury, the patient could undergo either above knee amputation or above reconstruction. Regarding both the MESS score of 6 and the desire of the patient, we initially chose limb salvage surgery as the treatment and informed consent was obtained from the patient.

\section{Initial surgery}

At the initial surgery, all devitalized soft tissue and bone were debrided and removed regardless of size. There was extensive soft tissue loss, especially on the left anterior knee, distal one-third of the femur and proximal one-third of the tibia. All bone fragments with no soft tissue attachment were removed. The popliteal area was explored and the neurovascular bundle was noted intact. There was a peroneal nerve defect of at least $10 \mathrm{~cm}$ with proximal fibula.
A unilateral external fixator was applied under emergency conditions and temporary skin grafting performed after irrigation and debridement of bone and soft tissue. In total, $22 \mathrm{~cm}$ bone loss resulted after debridement of bony substance.

Medical treatment consisted of tetanus prophylaxis, first-generation cephalosporin ( $2 \times 1 \mathrm{~g}$ /day for 5 days), ornidazole ( $2 \times 250 \mathrm{mg} /$ day for 5 days), aminoglycoside $(2 \times 80 \mathrm{mg} /$ day for 2 days) and antithrombotic treatment with low molecular weight heparin (enoxaparine sodium $60 \mathrm{mg}$ /day subcutaneously).

Wound irrigation and debridement continued at 48-hour-intervals until the wound was stable and clean. During the first two weeks, four more surgical debridements were performed. After the initial treatment, patient was transported to a tertiary hospital plastic surgery department. The plastic surgery team performed free tissue transfer to cover the defect with latissimus dorsi muscle. Six-months after the free flap, patient was transported to our department for treatment of bone loss (Figure 1a).

On physical examination, unilateral external fixation was observed on the affected side. Plantar flexion of the ankle was 40 degrees and there was no dorsiflexion. Sensorial loss was detected over the dermatomes of the sural, superficial peroneal and infrapatellar branches of the saphenous nerves. A sixteen centimeter bone defect on the distal femur and proximal tibia and $6 \mathrm{~cm}$ length discrepancy was detected. Trifocal type lengthening was planned with Ilizarov external circular fixator (ECF) due to the large amount of bone defect.
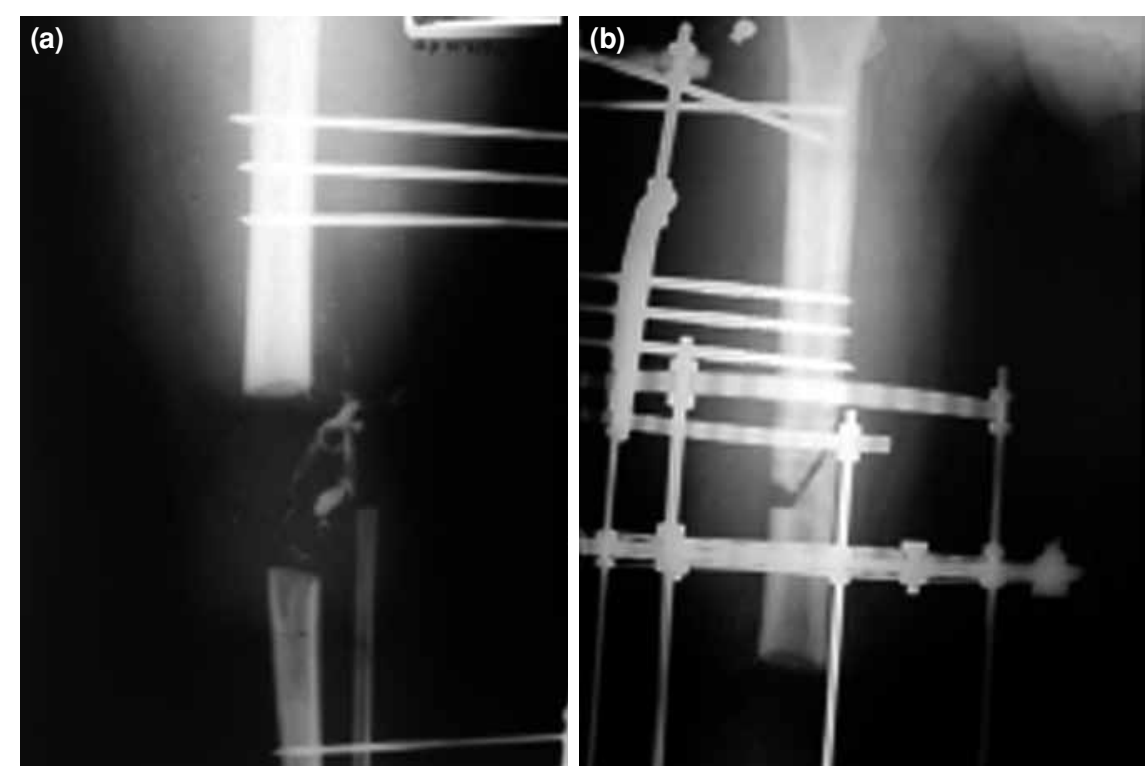

Figure 1. (a) Anteroposterior view after initial surgery. (b) Radiograph showing the femoral side after first osteotomy. 


\section{Surgery 1}

The trifocal ECF frame was prepared before surgery and applied to the left lower extremity (three levels proximal to the femoral defect and three levels distal to the tibial defect) under general anesthesia. Two Kirshner wires $(1.8 \mathrm{~mm})$ were applied to every level of the tibia and two half-pins $(6 \times 180 \mathrm{~mm})$ were applied to every level of the femur. Proximal femoral and distal tibial corticotomy were performed with a small osteotome after longitudinally incising the periosteum. Completion of the osteotomy was confirmed with X-ray and then the periosteum was re-sutured (Figure 1b). Distraction was started on the seventh postoperative day at a rate of $4 \times 0.25 \mathrm{~mm} /$ day on both the femoral side and the tibial side. During the distraction period, radiographs were taken every week. Equinovarus and strain had developed on the distal portion of the posteromedial muscle groups on the $16^{\text {th }}$ day of lengthening because of the total distraction rate of $2 \mathrm{~mm} /$ day so the lengthening speed was revised and continued at a rate of $4 \times 0.25 \mathrm{~mm} /$ day at the femur and $2 \times 0.25 \mathrm{~mm} /$ day at the tibia. Compression was applied to the defect side at a rate of $2 \times 0.25 \mathrm{~mm} /$ day. During the distraction and maturation period, the patient was mobilized with partial weight-bearing with axillary crutches. When the amount of lengthening reached $10 \mathrm{~cm}$ at the proximal side (femur) and $6 \mathrm{~cm}$ at the distal side (tibia), lengthening was stopped while compression to the defect side was continued until

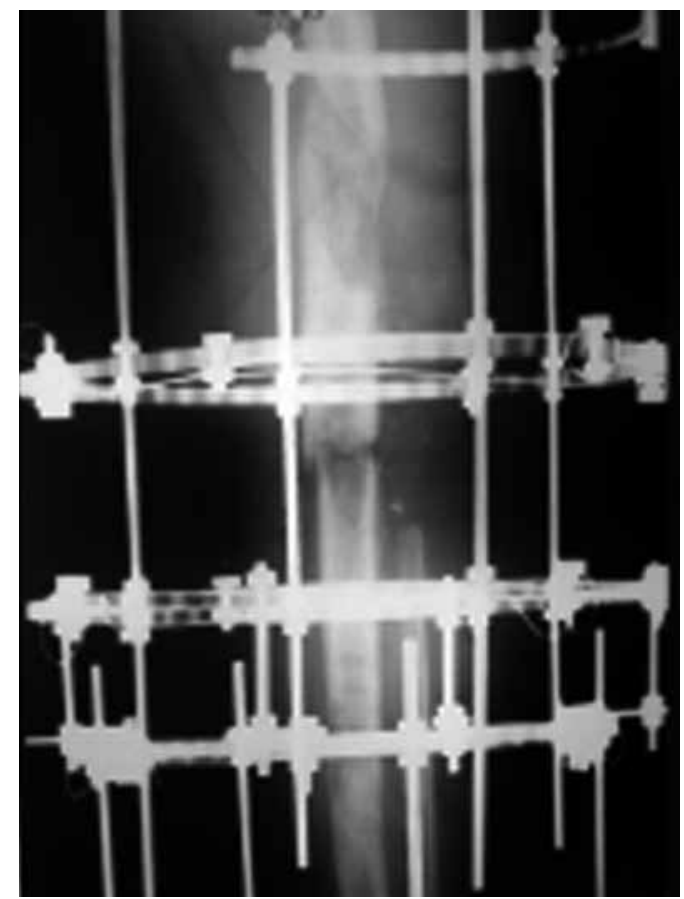

Figure 2. Radiography showing the arthrodesis between the femur and the tibia. distal femoral contact occurred with the proximal tibia. Ankle-foot orthosis with a height of $6 \mathrm{~cm}$ holding the ankle in 90 degrees was applied. The patient was mobilized with full weight-bearing as tolerated.

The fixator was removed when callus was seen in at least three cortices on plain radiographs in the $25^{\text {th }}$ postoperative month (distraction index: 8.75 day $/ \mathrm{cm}$, consolidation index: 35.62 day $/ \mathrm{cm}$ and external fixator index: $45 \mathrm{day} / \mathrm{cm}$ ).

After two years from the first surgery, reoperation for lengthening and repair of pseudoarthrosis was planned due to inadequate union at the docking site, pain and $6 \mathrm{~cm}$-length-discrepancy.

\section{Surgery 2}

A trifocal system similar to the first frame was applied to the patient under general anesthesia. The incision was made from the anterolateral part of the knee from healthy soft tissue to reach the docking site. A two-centimeter bone resection was done for renewing the docking site followed by acute compression. Demineralized bone matrix (DBM) and spongiform-type-autograft from iliac bone was applied to the compression site. Osteotomies were performed on the proximal tibia and distal femur for lengthening. Distractions were started on the seventh day at a rate of $2 \times 0.25 \mathrm{~mm} /$ day on the tibia and $4 \times 0.25 \mathrm{~mm} /$ day on the femur based on the previous experience. The length discrepancy with the sum of resections was $8 \mathrm{~cm}$. Full weight-bearing was allowed. Sufficient consolidation and union at the docking site were confirmed with four plane radiographs and the ECF frame was removed under general anesthesia on the $14^{\text {th }}$ postoperative month (Distraction index: 8.50 day $/ \mathrm{cm}$, consolidation index: 39 day $/ \mathrm{cm}$ and external fixator index: 48.75 day $/ \mathrm{cm}$ ) (Figure 2, 3).

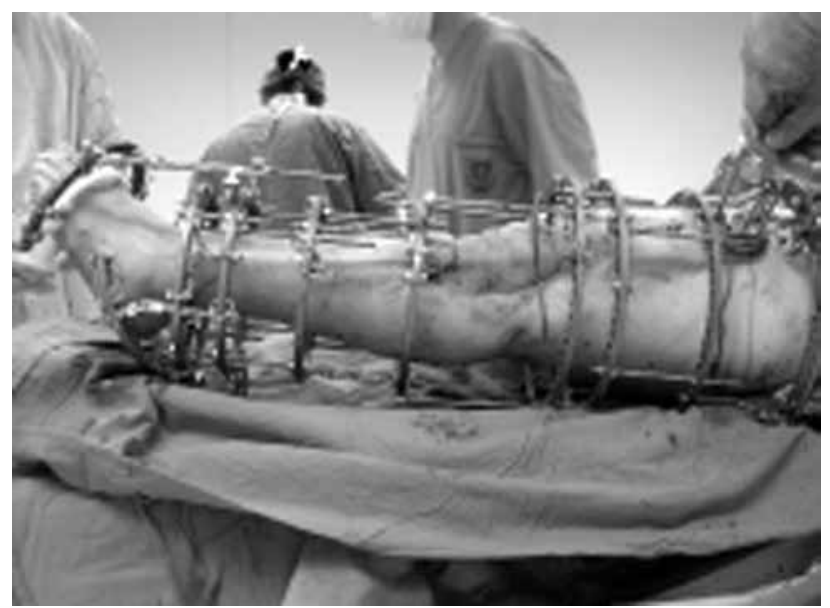

Figure 3. Intraoperative photo showing the femur, tibia and foot frame. 


\section{Surgery 3}

A third ECF was applied to the patient who still had $8 \mathrm{~cm}$ shortness 18 months after the second surgery. Osteotomies were performed at the former distraction sites on the femur within the monofocally prepared frame. In total, $6 \mathrm{~cm}$ distraction was achieved with the sum of lengthening from the femur and the system was removed after 10.5 months from the application.

\section{Surgery 4}

The patient was mobilized with a special cuff securing the extremity from fracture risk for one year. Equinus and varus deformities on his ankle advanced one year after the third surgery. Percutaneous achillotomy and correction of equinus deformity and triple foot arthrodesis with ECF were performed. A specially manufactured sole plate was used for mobilization. After confirmation of the healing of the foot arthrodesis with four plane radiographs, the system was removed on the fourth postoperative month.

After so many years of successful limb salvage surgery, we encountered a variety of complications, which -in many situations- had and have to be handled individually. The most frequent complication seen in our patient was superficial pin-tract infection which was treated by local care using betadine solution and oral antibiotics with resolution of the complication at all pin sites. The patient did not develop chronic osteomyelitis secondary to pin-tract infection. The other complications we encountered during the salvage surgery and follow-up period were wound infection, delayed union, vascular problems, neurological problems, increased number of operative interventions requiring re-hospitalization and fluctuation of the patient's psychological status. We successfully managed all of these complications individually with appropriate treatment methods.

The patient is on the third year after the last surgery and has complete arthrodesis on foot and knee, a $2 \mathrm{~cm}$ length discrepancy on the lower extremity and no infection of the bone or soft tissue. The patient is performing his daily activities without any aid but he has some disabilities when he wants to take something on the floor or when he has to sit in a bus. Despite a long treatment period, the patient is satisfied with his reconstructed extremity even if he cannot flex his knee (Figure 4a, b).

\section{DISCUSSION}

Land mines and high-energy gunshot injuries are classified as type IIIB and C according to the GustiloAndersson classification system. One of the major challenges is to decide whether to perform a limb salvage procedure or amputation due to the severity of the injury. ${ }^{[1-3,6]}$

Absolute indications for amputation with type IIIB and $\mathrm{C}$ open fractures are well defined but relative indications are not clear. ${ }^{[2,3,7]}$ When compared with
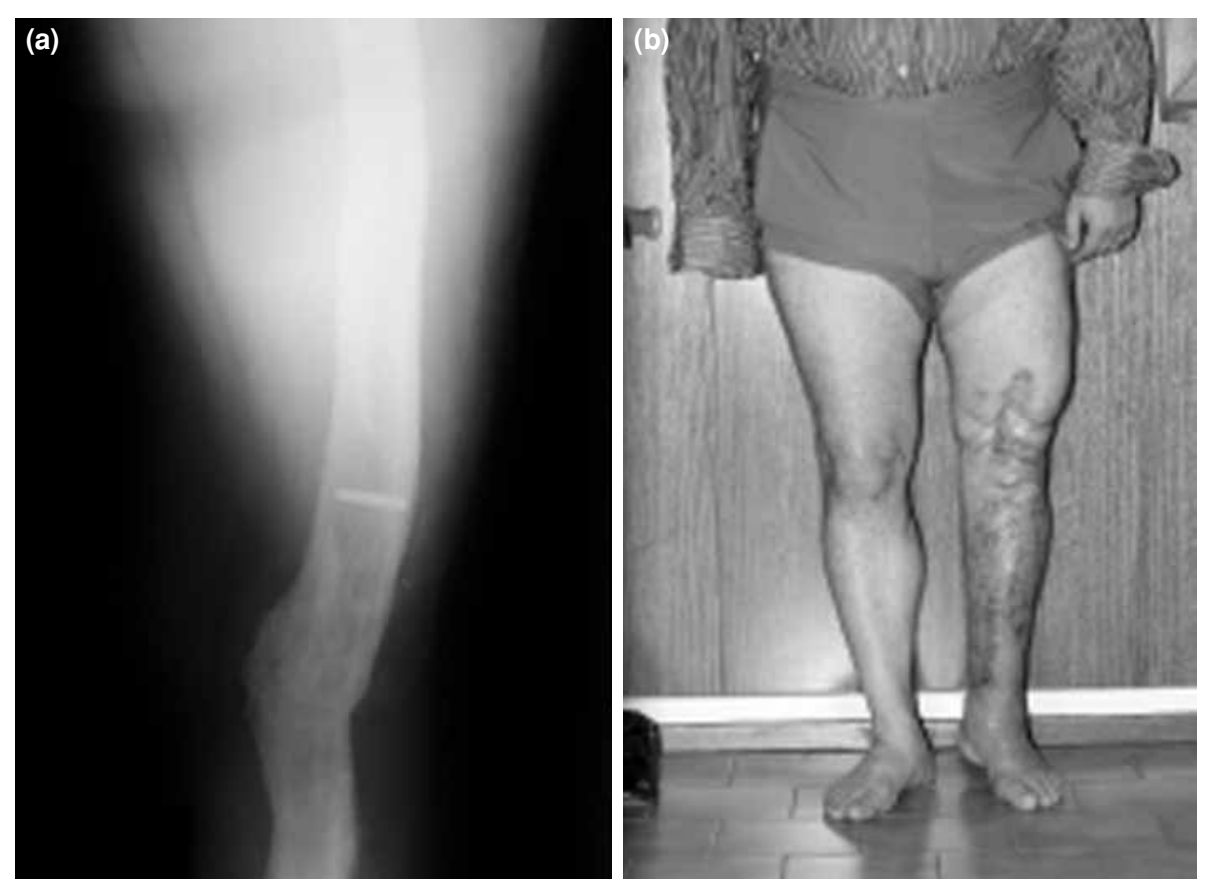

Figure 4. (a) Anteroposterior view showing complete union between the femur and the tibia after the treatment. (b) Final photo of the patient after the treatment. 
amputation surgery after type IIIC injuries, extremity salvage interventions need multidisciplinary specific approaches including orthopedic, plastic and cardiovascular surgery departments, repeated surgeries, long time hospitalizations and high cost efficiency. $\cdot^{[1-3,6]}$

Soft-tissue damage is the most important component of the injury, frequently dictating treatment and aesthetic disorders because flap and graft reconstructions may be the results of extremity salvage surgery. ${ }^{[3-6]}$ Despite these results, a salvaged extremity gives the patient good adaptation to social and daily life compared with amputation. Moreover, mobilization on his own extremity gives a patient extra satisfaction. ${ }^{[3-5,8]}$ The studies comparing the results of amputation and arthrodesis for type IIIC injuries are limited. Harris et al. ${ }^{[9]}$ compared the results of amputation, arthrodesis and tumor prosthesis among patients who had a tumoral lesion about their knees. Correlating with our study, Pelissier et al. ${ }^{[5]}$ performed a long-term follow-up study which found that although patients undergoing complex reconstruction for lower limb fractures reported poorer functional outcome, all felt that they preferred the reconstructed limb to an amputation. In this study, the functions of climbing up and down the stairs, showering without support and jumping easily over rough surfaces were observed in patients treated with arthrodesis. However, some difficulties were also observed in these patients including such activities as picking anything up from the floor or lying on the ground. Although the patients among the mentioned treatment groups of Harris et al..$^{[9]}$ had some degree of unsatisfaction, amputated patients were less willing to go outside their home because of phantom pain and skin irritation from the prosthesis.

Amputation has three major problems including functional loss, image problems and mood disorders. ${ }^{[3-5,9]}$ Co-morbidities related to amputation are risk of elevating amputation level, repeated stump problems, phantom pain, comfort problems in upper knee prosthesis. In addition, $28 \%$ of amputee patients have problems in finding jobs. ${ }^{[9]}$

Parallel to the literature, despite some negative effects of extremity salvage surgery including the long length of recovery, repeated surgeries, high costs and the long dependence of patients on hospitals, patients with high visual analog scale scores can have more social life with the help of the rescued extremity, continue their lives with their extremities and finally do not experience the disabilities and impairments of above knee prosthesis. Although there are some disadvantages, when evaluating a high-energy injured extremity, the chance of extremity salvage surgery should always be considered in the first plan.

\section{Declaration of conflicting interests}

The authors declared no conflicts of interest with respect to the authorship and/or publication of this article.

\section{Funding}

The authors received no financial support for the research and/or authorship of this article.

\section{REFERENCES}

1. Bosse MJ, MacKenzie EJ, Kellam JF, Burgess AR, Webb LX, Swiontkowski MF, Sanders RW, Jones AL, McAndrew MP, Patterson BM, McCarthy ML, Travison T, Castillo RC An analysis of outcomes of reconstruction or amputation after leg-threatening injuries. N Engl J Med. 2002;347:1924-1931.

2. Hansen ST Jr The type-IIIC tibial fracture: salvage or amputation? J Bone Joint Surg Am. 1987;69:799-800.

3. Georgiadis GM, Behrens FF, Joyce MJ, et al. Open tibial fractures with severe soft-tissue loss: limb salvage compared with below-the-knee amputation. J Bone Joint Surg Am. 1993;75: 1431-1441.

4. Dougherty PJ Open tibia fracture: amputation versus limb salvage. Opinion: below-the-knee amputation. J Orthop Trauma. 2007 Jan;21(1):67-8.

5. Pelissier P, Boireau P, Martin D, Baudet J Bone reconstruction of the lower extremity: complications and outcomes. Plast Reconstr Surg 2003;111: 2223-9.

6. Deren O, Ayhan M, Yakut M, Erdoğan B, Turan S, Adanalı G Avulsion Injuries of the Extremities. [Article in Turkish] Eklem Hastalık Cerrahisi 2002;13:145-152.

7. Kocaoğlu M, Çakmak M, Öztürkmen Y, Tuncay İ Ilizarov Method in Lengthening of Extremities. [Article in Turkish] Eklem Hastalık Cerrahisi 1996;7:50-55.

8. Oğuz E, Kömürcü M, Yıldız C, Kürklü M, Ateşalp S Analysis of ankle arthrodesis due to tibiotalar fracture caused by gun shot injury using Ilizarov External Fixator. [Article in Turkish] Eklem Hastalık Cerrahisi 2003;14:67-73.

9. Harris IE, Leff AR, Gitelis S, Simon MA Function after amputation, arthrodesis, or arthroplasty for tumors about the knee. J Bone Joint Surg Am. 1990 Dec;72(10):1477-85. 